\title{
SINERGIA
}

REVISTA DO INSTITUTO DE CIÊNCIAS ECONÔMICAS, ADMINISTRATIVAS E CONTÁBEIS (ICEAC)

\section{CAPTAÇÃO DE RECURSOS E PRÁTICAS GERENCIAIS EM ORGANIZAÇÕES DA SOCIEDADE CIVIL DO MUNICÍPIO DE LUCAS DO RIO VERDE}

\author{
ANA CLAUDIA DA CONCEIČ̃̃ CARVALHO
}

AMANDA PIMENTEL PAES*

\begin{abstract}
RESUMO
Este trabalho tem como objetivo identificar e analisar as formas de captação de recursos e as práticas gerenciais para prestação de contas em Organizações da Sociedade Civil (OSC). Como forma de difundir o contexto enfrentado por estas organizações sem fins lucrativos, propôs-se o estudo de suas práticas gerenciais desde a captação de recursos à prestação de conta ao grupo, à sociedade e ao governo na condição de financiadores e beneficiados das OSCs. Foi realizada uma pesquisa de abordagem qualitativa por meio do estudo de múltiplos casos representados por OSCs atuantes no Município de Lucas do Rio Verde - MT. Após análise dos dados obtidos, os resultados encontrados indicam relação entre a captação de recursos principal e a escolha das práticas gerenciais utilizadas pelas associações. Concluise que, no contexto analisado, indica-se o uso de sistemas integrados para prestação de contas para atendimentos às demandas legais dos recursos de origem pública e o uso de práticas gerenciais para atender às pessoas jurídicas que direcionam recursos a essas entidades. As contribuições estão no padrão encontrado nas associações em função da evolução da forma de capitação de recursos, principalmente, quando ligadas aos recursos privados.
\end{abstract}

Palavras-chave: Capitação de Recursos; Práticas Gerenciais; Terceiro Setor; Organizações da Sociedade Civil; OSC.

\section{ABSTRACT}

This work aims to identify and analyze the forms of fundraising and managerial practices for accountability in Civil Society Organizations (CSO). As a way of disseminating the context faced by these non-profit organizations, the study of their management practices was proposed, from fundraising to accountability to the group, society and the government as funders and beneficiaries of CSOs. A qualitative approach research was carried out through the study of multiple cases represented by CSOs working in the municipality of Lucas do Rio Verde - MT. After analyzing the data obtained, the results found indicate a relationship between the main fundraising and the choice of managerial practices used by the associations. It is concluded that, in the context analyzed, it indicates the use of integrated systems for rendering accounts to meet the legal demands of resources of public origin, and the use of managerial practices to serve legal entities that direct resources to these entities. The contributions are in the pattern found in associations due to the evolution of the form of resource capitation, especially when linked to private resources.

Keywords: Resource Capitation; Management Practices; Third sector; Civil Society Organizations; OSC.

Recebido em: 27-07-2021 Aceito em: 10-11-2021

\section{INTRODUÇÃO}

O cenário de incerteza, transformações constantes, desigualdades sociais, a formação e atuação de Organizações Sociais apresentam-se como promissoras global e nacionalmente (ROCHA; GONÇALVES, 2017). Tais organizações são classificadas como Terceiro Setor por não possuir fins lucrativos e manter objetivos sociais que atendam a sociedade na ausência ou na omissão do poder público (SANTOS; NEGRÃO; SABOYA, 2018).

Dessa forma, questões como saúde, educação, meio ambiente, assistência social, cultura, entre outros são os contextos mais comuns para atuação das organizações do Terceiro Setor. Dentre essas, incluem-se as Organizações da Sociedade Civil (OSC) que consistem no trabalho de equipes voluntariadas, sem a intenção de obter lucros e que dependem da captação de recursos (SILVA; VASCONCELOS, 2016).

O principal desafio das OSCs está em manter, diariamente, as atividades da instituição, uma vez que dependem exclusivamente de recursos externos provenientes do setor privado, organizações internacionais, governo e pessoas físicas solidárias à causa. Esses recursos são imprescindíveis à manutenção e ao

\footnotetext{
Discente do Curso de Ciências Contábeis do Centro Universitário La Salle (UniLaSalle).

"Mestre em Ciências Contábeis pela Universidade Regional de Blumenau (FURB). Docente do Centro Universitário La Salle (UniLaSalle) de Lucas do Rio Verde - MT. E-mail: amandapimentelpaes@gmail.com
} 
funcionamento das organizações e seus projetos, o que reforça a relevância de uma captação de recursos eficaz e de gestão para prestação de contas adequadas a fim de repassar a seus financiadores credibilidade e retorno social pelos recursos investidos.

A gestão nas OSCs é realizada por indivíduos eleitos por associados cuja função é efetuar a melhor aplicação dos recursos a fim de alcançar os objetivos administrativos da organização, prestar contas ao grupo, sociedade e governo, bem como manter o controle das atividades econômico-financeiras. Apesar de definida suas funções, a gestão de recursos para prestação de contas é um processo contínuo e dinâmico que, em geral, representa um dos maiores obstáculos para organizações do Terceiro Setor à medida que nem sempre são utilizadas técnicas apropriadas para gestão efetiva (BORGES; DA COSTA; RAZA, 2018).

Como um instrumento de controle, a prestação de contas exige conhecimento por parte do administrador para registrar, organizar, avaliar e cumprir com as metas propostas e com a real transparência da aplicação dos recursos captados para atingir os objetivos dos projetos (BORGES; DA COSTA; RAZA, 2018). Não se distinguindo das demais organizações, as OSCs devem manter práticas contábeis adequadas e escrituração em conformidade com as normas legais para a realização da prestação de contas (SANTOS, 2010; MENDONÇA; SEGATTO, 2014). Embora a gestão nas OSCs tenha evoluído, a velocidade e frequência de mudanças combinadas ao contexto de crise ou recessão torna a captação de recurso ainda mais escassa (LORCA; AVRICHIR, 2020).

Esta escassez de fontes de recursos públicos ou privados condiciona a sobrevivência das organizações do terceiro setor, ficando mais evidente em contexto de crise econômica e política (SANTOS; NEGRÃO; SABOYA, 2018). Consequentemente, é demandada maior profissionalização da gestão em OSCs a fim de cumprir as expectativas de seus financiadores de recursos para manter um nível de captação necessário à sua sobrevivência mesmo em tempos de crise econômica. A profissionalização da gestão beneficia a captação de recursos a partir de informações divulgadas pelas próprias OSCs quanto à: (i) eficiência na alocação de recursos; (ii) a estabilidade financeira; (iii) a reputação; e (iv) a missão da entidade e situação de seus beneficiários (TRUSSEL; PARSON, 2008). Tais informações fornecem subsídios para avaliar o desempenho das organizações, sendo fundamentais para sustentar sua continuidade (CUNHA; MATIASPEREIRA, 2012).

Portanto, apesar de organizações do terceiro setor apresentarem aspectos estruturais e operacionais distintos, principalmente, no que concerne a sua fonte de receita e aos objetivos institucionais (GODOY; RAUPP; TEZZA, 2016), o ambiente externo no qual estão inseridas e do qual dependem é o mesmo do primeiro e do segundo setor, colocando em check as posturas adotadas pelas OSCs quanto ao uso de práticas gerencias que proporcionem maior transparência, avaliação e monitoramento de suas atividades a fim de fomentar a captação de recursos necessários (SILVA; COSTA; GÓMEZ, 2011; SANTOS; SOUZA; VENDRUSCOLO, 2021).

Apesar dos estudos encontrados na literatura sobre fatores estratégicos para divulgação de informações (CUNHA; MATIAS-PEREIRA, 2012), custos no terceiro setor (SANTOS; SOUZA; VENDRUSCOLO, 2021), marketing na captação de recursos (CAMPOS et al, 2020) e prestação de contas e captação de recursos (ANANIAS et al., 2020), poucos se dedicam à compreensão de práticas gerenciais adotadas pelas OSCs (INNOCENTI; GASPARETTO, 2021). Cenário que propõe lacunas de pesquisas quanto ao uso de práticas gerenciais que favoreçam não apenas a prestação de contas, mas a manutenção da captação de recursos e continuidade dessas entidades. Do exposto, questiona-se: Quais as formas de captação de recursos e as práticas gerenciais para prestação de contas em Organizações da Sociedade Civil? Decorrente da questão de pesquisa, definiu-se como objetivo identificar e analisar as formas de captação de recursos e as práticas gerenciais para prestação de contas em Organizações da Sociedade Civil. Do objetivo geral, elaboraram-se os objetivos específicos:

a) compreender as estratégias de captação de recursos recorrentes em Organizações da Sociedade Civil;

b) identificar as práticas gerenciais para prestação de contas em Organizações da Sociedade Civil;

c) analisar a relação entre a captação de recursos com as práticas gerenciais para prestação de contas realizadas em Organizações da Sociedade Civil.

Justifica-se a investigação realizada, neste estudo, pela relevância do papel desempenhado pelas organizações do Terceiro Setor perante a sociedade, exigindo atenção para a manutenção de suas ações e de projetos desenvolvidos para desenvolvimento local. Conforme o Mapa das OSCs administrado pelo Instituto de Pesquisa Econômica Aplicada (IPEA), em 2019, no Brasil, contavam 781.921 OSCs registradas e com concentração de $47 \%$ em Desenvolvimento e Defesa dos Direitos, $20 \%$ em Religião e $12 \%$ em Cultura e Recreação, indicando a abrangência do Terceiro Setor. Portanto, compreender as dificuldades e as soluções encontradas para a continuidade dessas organizações é fundamental para atrair financiadores (SANTOS; NEGRÃO; SABOYA, 2018).

A realização desta pesquisa contribui academicamente para analisar o contexto de organizações 
atuantes na sociedade que visam mudar a condição social e econômica de indivíduos beneficiados por seus projetos. Sendo a contabilidade uma ciência social que transforma as informações econômicas e sociais em uma linguagem financeira, o seu uso por OSCs, na captação de recursos e na profissionalização do seu modelo de gestão, é uma contribuição tanto para a área financeira quanto para a social, difundindo a realidade organizacional singular das OSCs e permitindo que a comunidade interessada e administradores de outras OSCs se beneficiem dos achados do. estudo

A disseminação científica da contabilidade gerencial aplicada ao terceiro setor também pode contribuir para alcançar outras fontes de financiadores e voluntários que compartilham interesses por causas sociais e seu processo de realização desde a captação de recursos até a gestão e a prestação de contas para reforçar parcerias com o Terceiro Setor.

\section{FUNDAMENTAÇÃO TEÓRICA}

Nesta seção, são fundamentados os temas abordados, na pesquisa, a fim de analisar o fenômeno proposto, iniciando-se com uma revisão da literatura referente ao terceiro setor na forma de Organizações da Sociedade Civil (OSC) e finalizando com a captação e com a gestão da prestação de contas nas OSCs.

\subsection{Terceiro Setor e Organizações da Sociedade Civil}

Incluem-se, no terceiro setor, as entidades não governamentais sem fins lucrativos, com o objetivo de promover serviços de caráter público que contribuam para a redução de problemas econômicos e sociais (SANTOS; SILVA, 2015). Enquanto nos termos primeiro e segundo setores inclui-se o Estado e o Mercado, respectivamente, o terceiro setor é utilizado pelas ciências sociais para classificar as OSCs que prezam pela satisfação social em vez do retorno financeiro (OLIVEIRA JUNIOR, 2018).

Apesar da relevância social, o termo terceiro setor não é adequadamente compreendido. Medeiros (2017) apresenta o terceiro setor como mediador entre o primeiro e segundo setor e a sociedade, isso por compartilhar das características dos dois primeiros setores. Porém, com um objetivo diferenciado, a busca da assistência social e do equilíbrio dos indivíduos na sociedade. A associação dos três setores e da sociedade pode ser compreendida conforme a Figura 1.

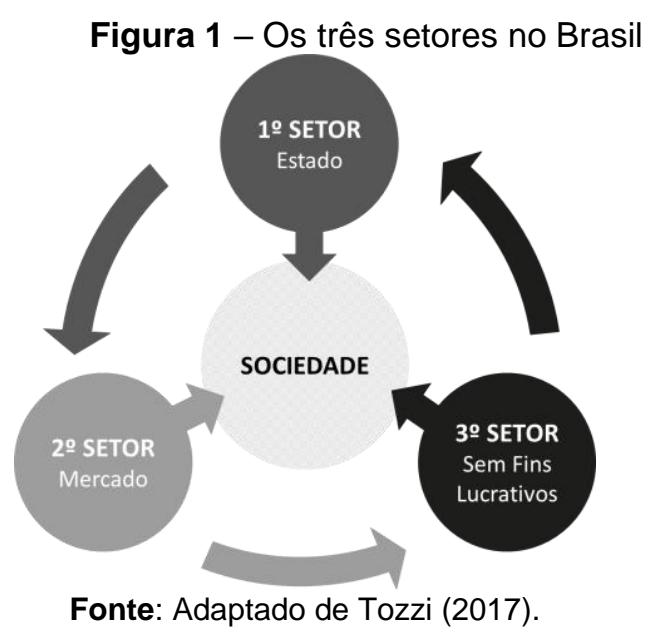

No primeiro setor, encontram-se as entidades governamentais de administração direta no poder das três esferas do governo, como União, Estados, Distrito Federal, Territórios, Municípios e as autarquias (OLIVEIRA, 2018). O segundo setor é composto por todas as organizações com fins lucrativos e com interesse em benefícios particulares ou próprios (MEDEIROS, 2017) enquanto as demais organizações privadas, regulamentadas pela Lei 9.790/99, que não possuem fins lucrativos, enquadram-se no terceiro setor (BORGES; DA COSTA, 2018).

A relação entre os três está na captação de recursos e objetivos sociais à medida que o terceiro setor pode captar recursos dos outros dois e esses podem se beneficiar pelas ações e pelos projetos desenvolvidos pelo terceiro setor que vai além dos objetivos econômicos. Na realidade, as OSCs promovem ações com objetivo de geração de empregos, participação nas economias combinadas ao fornecimento de bens e serviços, empenhando um papel "político-social" frente ao primeiro e ao segundo setor (RIFKIN, 1996).

As OSCs surgem pela vontade de pessoas que se juntam para conquistas objetivos em comum, buscando suprir necessidades sociais como escolas para atender às pessoas com necessidades especiais, sindicatos, associações, entre outros. A Constituição Federal de 1988 foi a primeira a atribuir, de maneira 
expressa, o dever à sociedade civil de contribuir, por meio de organizações privadas, sem fins lucrativos, para a consecução dos objetivos do Estado brasileiro. São diversos os artigos da Carta Magna que imputam o dever contribuição (OLIVEIRA JUNIOR, 2018). A Lei Federal 9.790, em seu artigo $1^{\circ}$, diz:

Art. 1을 Podem qualificar-se como Organizações da Sociedade Civil de Interesse Público as pessoas jurídicas de direito privado sem fins lucrativos que tenham sido constituídas e se encontrem em funcionamento regular há, no mínimo, 3 (três) anos, desde que os respectivos objetivos sociais e normas estatutárias atendam aos requisitos instituídos por esta Lei.

O Terceiro Setor é composto por organizações sociais, entidades sem fins lucrativos, voltadas à prestação de serviços públicos não exclusivos do Estado, com o intuito de atender a demandas que não são alcançadas pelo ente público, contribuindo para o desenvolvimento social (CAMARGO, 2018; ARAÚJO et al. 2021). As organizações do terceiro setor são organizações diversas, tanto como atua na sociedade, na sua forma, em seus objetivos organizacionais, como no tamanho da instituição. Essas organizações tentam desenvolver o resgate da cidadania dentro de cada contexto, propondo ações sociais, com prática de trabalhos voluntários, doações e parcerias.

No contexto dos governos totalitários, surgiram as organizações não governamentais (ONGs) a partir dos movimentos sociais de resistência à ditadura militar (PARENTE, 2012). No cenário social, a urbanização e industrialização fizeram com que surgissem inúmeras associações profissionais, associações de classe e sindicatos (OLIVEIRA JUNIOR, 2018). De acordo com o código civil, as Organizações da Sociedade Civil podem ser instituídas em dois formatos, associações e fundações. O código civil, em seu artigo 44, da Lei 10.402, de 2002, diz:

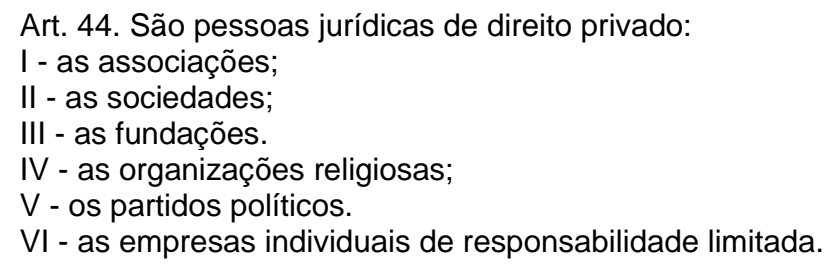

As pessoas jurídicas de direito privado são instituídas por iniciativa de particulares, podendo ser subdivididas nos termos dos artigos 44 do Código Civil em: associações e fundações (OLIVEIRA, 2018). A seguir, define-se, conceitualmente, as Associações e as fundações. Segundo o Código Civil, Lei no 10.406, de 10 de janeiro de 2002, define associações como a "união de pessoas que se organizam para fins não econômicos" (art. 53). O direito à livre associação para fins lícitos está previsto e assegurado pela Constituição Federal no artigo 5을 inciso XVIII (NATRIELLI NETO; GUIMARO JUNIOR, 2011).

As fundações, por sua vez, constituem-se numa universalidade de bens ou direitos, dotados de personalidade e destinados a uma determinada finalidade social, estabelecida pelo seu instituidor (ANDRADE et al., 2015). Compreendido que as organizações da sociedade civil podem ser formadas sob a forma de associações ou fundações, é importante conhecer as formas de qualificação que essas entidades podem receber em razão de sua natureza (ARAÚJO et al. 2021).

Atualmente, a literatura divide o Terceiro Setor em quatro espécies de organização, a saber: serviços sociais autônomos, entidades de apoio, Organizações Sociais (OS), Organizações da Sociedade Civil de Interesse Público (OSCIP) e Organizações da Sociedade Civil (OSC), que, embora apresentem denominações similares, são modelos completamente distintos (OLIVEIRA; JUNIOR, 2018). As associações, da mesma forma que as sociedades, constituem um agrupamento de pessoas com uma finalidade comum. No entanto, as associações perseguem a defesa de determinados interesses, sem ter o lucro como objetivo.

\subsection{Captação de Recursos e Gestão da Prestação de Contas}

O Terceiro Setor é reconhecido pelas soluções positivas que vêm encontrando para toda a sociedade brasileira. No processo de transformação da sociedade, o mesmo vem encontrando respostas criativas para ajudar a mudar o futuro do Brasil (BORGES; COSTA, 2018). Apesar de prestar serviços voluntários à sociedade, o setor não está dispensado de despesas, como conta de água, luz, aluguel, material de expediente, limpeza, higiene, entre outros.

Para custear suas operações, a captação de recursos é imprescindível. Contudo, essa captação não se resume a auxílios financeiros, mas abrange as áreas de pessoal, infraestrutura e materiais necessários para o bom funcionamento da organização (MIRANDA; OLIVEIRA 2019). Independentemente de qual setor as empresas façam parte, todas precisam de recursos para suprir suas despesas decorrentes da sua atividade (MEDEIROS 2017). 
Todas as organizações, sem fins de lucros ou não, necessitam de recursos para viabilizar sua atividade, de forma que se obtenha resultado positivo com a operação. (SILVA; VASCONCELOS, 2016). As organizações encontram bastante dificuldade na captação de recursos, e muitas instituições têm uma pessoa ou um setor responsável por essa ação (MIRANDA, OLIVEIRA, 2019). De acordo com Andrade, apud, Medeiros (2017, p. 23).

Quando se pensa na captação de recursos, há uma preocupação constante do tipo de interferência que pode ocorrer: a situação de dependência e subordinação, abominada pelas organizações de assistência social. É claro que qualquer financiamento: de empresas, do governo, das organizações de cooperação internacional, pode interferir de alguma forma nos objetivos e nas formas de atuação da organização, mas tal interferência só pode ser aceita se contribuir para a maximização dos resultados.

As organizações precisam desenvolver estratégias internas que garantam maior autonomia na defesa de seus interesses dentro do processo de interação com o meio externo para que haja coalizões benéficas para todos os envolvidos (MELO, 2018). A maioria dos recursos de financiamento das Instituições é de origem conforme menciona Tozzi (2017) na Figura 2:

Figura 2 - Financiamento das ONG's no Brasil

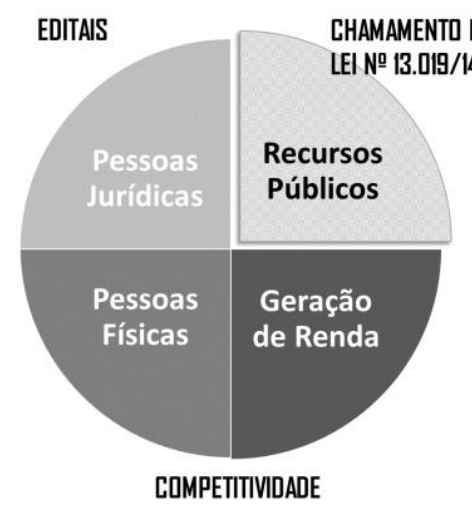

Fonte: Adaptado de Tozzi (2017).

As origens dos recursos podem vir de diferentes parcerias, o que é benéfico para que as instituições possam buscar várias fontes de recursos e, assim, manter o equilíbrio entre as origens de seus financiamentos, complementando recursos injetados por pessoas jurídicas, públicas ou físicas e os gerados de forma própria para manter sua sustentabilidade e não comprometer sua existência (MIRANDA; OLIVEIRA, 2019).

As quatro fontes de recursos da Figura 2 podem financiar as OSCs de formas distintas. No caso das pessoas jurídicas, a captação é realizada por meio de um edital lançado pela empresa a fim de que associações interessadas possam concorrer e angariar recursos, devendo submeter-se aos procedimentos do edital podendo ou não ser contemplada (TOZZI, 2017). Embora menos burocrático, os recursos de pessoas físicas não são tão comuns, tais recursos em geral são repassados por meio de incentivo fiscal pela restituição do imposto de renda, obtidos quando a relevância e a credibilidade da OSC perante a sociedade são visíveis (MORAIS et al., 2006).

A terceira fonte é de recursos públicos governamentais, subvenções sociais e auxílios dados por contratos, convênios ou termos de parceria, mediante a apresentação e a aprovação de projetos desde que as OSCs obedeçam aos requisitos dos editais (ONOFRIO, 2020). A captação de recursos do governo teve mudanças com a Lei $n^{\circ} 13.019 / 2014$, que entrou em vigor para recursos públicos municipais a partir de $1^{\circ}$ de janeiro de 2017. A lei expressa que, para o município financiar uma Associação filantrópica, terá que fazer através de chamamento público que deverá lançar edital para financiar algum tipo de projeto social (TOZZI, 2017).

A última forma de captação é por meio de geração de renda própria da OCS, na qual a gestão cria estratégias para gerar recursos que não dependam de doações do governo ou de pessoas jurídicas ou públicas, obtendo autonomia financeira e garantia da continuidade do trabalho social desenvolvido. O que é relevante quando considerado que a sustentabilidade da OSC depende da congruência de interesse entre o financiador ou o doador e a OSC e que está não se sustenta, a existência da OSC é comprometida.

No Brasil, o terceiro setor carece de uma legislação sistematizada e moderna e desenvolvida a ponto de estimular participações sociais e financiamento de projetos para, assim, conseguir cumprir com os objetivos elementares da República, previstos no artigo $3^{\circ}$ da Constituição, que fala na construção de uma 
sociedade livre, justa e solidária, com a erradicação da pobreza e da marginalização, com a redução das desigualdades sociais e com a promoção do bem de todos sem discriminação (MEDEIROS, 2017).

Outra barreira enfrentada pelas associações é o gerenciamento de todas as atividades da instituição, tais como: prestação de contas, captação de recursos, planejamento, auditoria, gestão de pessoas e marketing (SILVA, 2010). As Entidades filantrópicas brasileiras, ao longo de cinco séculos, vieram ampliando seu espaço de atuação em função das próprias demandas sociais da população e de mudanças institucionais diversas, intensificadas (SILVA, 2010).

Atualmente, o Terceiro Setor assume o papel de um importante parceiro do Governo, pois, otimizando o resultado final, é através dele e de todo o conhecimento sistematizado e coletado, ao longo dos anos, que o governo pode estabelecer planos de ação e metas de controle. Por sua vez, a iniciativa privada começa a exercer um importante papel para o Terceiro Setor, agregando a ele conhecimentos práticos, ricos em sua base e já implementados, de alguma forma, na sociedade, com indicadores de resultados e perspectivas de aprimoramento (SILVA,2007).

É de responsabilidade do gestor de uma organização sem fim lucrativos análises, decisões e atuações, relacionadas com os meios financeiros necessários à atividade da Entidade. Assim, a função financeira integra todas as tarefas ligadas à obtenção, à utilização e ao controle de recursos financeiros, sejam eles por meios de fluxo de caixa, relatórios diversos, orçamento anual, seja administração estratégica junto aos seus membros (SANTOS; SILVA, 2015).

De acordo com Kaplan e Norton (2001), as Organizações não lucrativas têm, tipicamente, a dificuldade de definir com clareza a sua estratégia. A maioria de seus planos estratégicos consiste numa lista de programas e iniciativas e não nos resultados que a Organização pretende atingir, ou seja, a missão e a visão da Organização não estão articuladas. A prestação de contas tem grande importância na organização que ela se desenvolve, seja de caráter público, seja privado, já que é uma obrigação que tem como contrapartida um direito: o direito da requisição da prestação de contas. A prestação de contas prevê a existência de um conjunto de leis e instituições com a missão de supervisionar o cumprimento desta obrigação (BORGES; COSTA; RAZA, 2018).

No mesmo sentido, a prestação de contas se entende como o processo político focalizado na procura da sustentação e da credibilidade das Instituições públicas e do Governo de um país, relacionando esta premissa à capacidade atual das Organizações em função da geração de recursos suficientes e do percurso do caminho de acordo com a visão estabelecida, definindo o objetivo a ser a tingido no longo prazo (MELO; SOUZA VASCONCELOS, 2017).

A prestação de contas é uma ferramenta que propicia ao agente demonstrar a quitação de suas obrigações junto ao principal de uma organização com relação ao gerenciamento dos recursos que lhe foram confiados, o que se faz importante diante das relações construídas socialmente para que seja possível garantir a sobrevivência das instituições (NAKAGAWA; RELVAS; DIAS, 2007). Os coordenadores e dirigentes do Terceiro Setor necessitam, constantemente, de informações para tomar decisões. De acordo com Ténorio, apud, Morgan; Benedicto (2009, p. 09):

Para gerenciar, se deve ter em mente a busca da eficiência, da eficácia e da efetividade; deve-se planejar, organizar, dirigir, controlar e tomar decisões estratégicas, táticas ou operacionais. Essas condições inerentes ao ato de gerenciar, no entanto, contrastam como que se observa no dia-a-dia das OTS, que por suas características peculiares e pela própria formação de seu corpo dirigente, mais voltado para as atividades finalísticas da organização, exercem a gestão tendo por base a intuição e o bom senso, carecendo de embasamento técnico em administração.

Neste contexto, a controladoria pode suprir essa necessidade por meio do sistema de informações gerenciais, atuando como um instrumento de gestão que poderá contribuir, disponibilizando as informações necessárias para as diversas etapas do processo decisório. Pois as fases do processo de gestão têm os seguintes objetivos: identificar o problema ou situação que requer a tomada de decisão; identificar as alternativas de ação em face do problema; analisar as repercussões de cada uma delas para poder avaliar a melhor; e escolher a melhor opção (MORGAN; BENEDICTO, 2009). Apesar de seu caráter social, a preocupação dos financiadores é comum e deve ser considerada como primordial, visto sua contribuição para que as OSCs alcancem seus objetivos.

Como apontado por Milani Filho e Milani (2011) e Celegatti et al. (2021), tanto financiadores quanto colaboradores passam, cada vez mais, requerer informações sobre a aplicação de recursos e resultados dessas entidades. Focando na etapa final de prestação de contas, Ananias et al. (2020), ao analisar as contribuições da prestação de contas contábil para a captação de recursos nas organizações do Terceiro Setor se observa que, apesar da presença de planejamento de uso de recursos, as entidades encontram dificuldade em conseguir parcerias de doadores e voluntários permanentes e ausência de divulgação periódica de demonstrativos contábeis por parte de muitas dessas entidades. 
Em seu estudo, Celegatti et al. (2021) vão além da contribuição contábil para abordar a adoção de boas práticas de governança corporativa em uma entidade do terceiro setor, sua análise se dá pelo Índice de Adoção de Práticas de Governança Corporativa (IAPGC), no qual a entidade em questão atendia a poucos princípios do IAPGC. Vasconcelos et al. (2021) evidenciaram práticas utilizadas no processo captação de recursos em organizações do terceiro setor, indicando deficiências e riscos na execução dessas práticas. $O$ fato é que diversas informações podem ser utilizadas na captação de doadores de recursos, desde relatórios e demonstrações financeiras a Marketing, Campanhas, eventos que gerem sensibilização e mobilização (CUNHA; MATIAS-PEREIRA, 2012; CAMPOS et al, 2020.

Todavia, conforme apontado por Trussel e Parsons (2008), o que afeta a decisão do doador em disponibilizar recursos a uma entidade é poder decidir sobre sua eficiência, estabilidade financeira, por meio da divulgação de informações e reputação da entidade. Dessa forma, as organizações do terceiro setor estão envolvidas em um ambiente diversificado, complexo e dinâmico, que exige uma gestão diferenciada no sentido de atender eficientemente a toda essa demanda, com o objetivo de gerar as informações que facilitem o processo de tomada de decisões, colaborando com os gestores na tarefa de alcançar a eficácia organizacional.

\section{PROCEDIMENTOS METODOLÓGICOS}

Buscando identificar e analisar as formas de captação de recursos e as práticas gerenciais para prestação de contas em Organizações da Sociedade Civil, realizou-se uma pesquisa que caracterize como do tipo descritiva, com abordagem qualitativa, utilizando-se de um estudo de caso múltiplos para abordagem do fenômeno estudado. Para melhor entendimento e compreensão, conceituam-se os métodos e as técnicas utilizadas para pesquisa.

O objetivo principal das pesquisas descritivas é descrever fenômenos, características de uma determinada população e, ainda, estabelecer relações entre as variáveis. Tem como características a utilização de técnicas padronizadas de coleta de dados, podendo ser incluídas, neste grupo, as pesquisas que têm por objetivo levantar as opiniões, atitudes e crenças de uma população (GIL et al., 2002).

A abordagem é qualitativa, utilizando-se de um estudo de casos múltiplos para abordagem do fenômeno estudado. É um tipo de método de investigação de base linguístico-semiótica usado, principalmente, em ciências sociais que costumam considerar técnicas qualitativas todas aquelas diferentes da pesquisa estatística e do experimento científico, como entrevistas abertas, grupos de discussão ou técnicas de observação de participantes (GIL, 2008). As pesquisas com abordagem qualitativas coletam informações que não buscam apenas medir um tema, mas descrevê-lo, usando impressões, opiniões e pontos de vista.

Tal abordagem, quando aplicada em estudo de casos, proporciona uma compreensão mais detalhada da questão de pesquisa proposta nesta pesquisa, proporcionando análises mais profundas. Isso pelo fato de, conforme Gil (2008), o estudo de caso focar na busca de conhecimento amplo e detalhado, direcionado a um objeto de análise, distinguindo-se de outros delineamentos de pesquisa.

As Organizações da Sociedade Civil estudas compreendem 03 (três) Associações do terceiro setor que oferecem serviços gratuitos nas áreas de ensino, serviços sociais, culturais e espirituais. O contato com os responsáveis das OSCs decorreu por meio eletrônico, em 06 de outubro de 2020, e presencial, nos dias 02 e 16 de outubro de 2020, por meio do qual foi apresentada a proposta de pesquisa e o compromisso de confidencialidade. Junto aos responsáveis, foram estabelecidos os indivíduos a serem entrevistados.

A esses, foi aplicado o roteiro de pesquisa que possuía três dimensões para caracterização do entrevistado, formas de captação de recursos (DALL'AGNOL, Camila Fortuna et al., 2017) e práticas de gestão (OLIVEIRA, 2016) e prestação de contas (DALL'AGNOL, Camila Fortuna et al., 2017) adotadas pelas OSCs. A caracterização dos entrevistados é apresentada no Quadro 1.

\begin{tabular}{|c|c|c|c|c|}
\hline Quadro 1 & Caracterização dos Entrevistados \\
Associação & Entrevistado & Função & $\begin{array}{c}\text { Tempo na } \\
\text { Associação }\end{array}$ & Formação \\
\hline A & Entrevistado A1 & Coordenadora & 4 anos & Assistente Social \\
\hline B & Entrevistado B1 & Vice-Presidente & 14 anos & $\begin{array}{c}\text { Pedagoga/ } \\
\text { Publicitaria }\end{array}$ \\
\hline C & Entrevistado C1 & Presidente & 1 anos e 6 meses & Advogada \\
\hline
\end{tabular}

Fonte: Dados da Pesquisa.

Em função da Pandemia do COVID-19, o Entrevistado C1, do grupo de risco, preferiu não realizar a entrevista de forma presencial ou virtual, respondendo ao roteiro manualmente e o enviando, por email, às autoras da pesquisa. Após a realização as entrevistas, essas foram transcritas e categorizadas, 
simultaneamente, a fim de subsidiar a discussão das dimensões de análise. Os resultados são apresentados e analisados na seção seguinte.

\section{APRESENTAÇÃO DOS RESULTADOS}

Nesta seção, apresentam-se os resultados obtidos a partir das dimensões de análise propostas pelo objetivo do estudo a fim de alcançar maior compreensão do fenômeno estudado.

\subsection{Caracterização das Associações}

Para análise de resultados, foram entrevistadas três Organizações da Sociedade Civil. A Associação A atua desde $o$ ano de 2016, prestando serviço de oficinas culturais, como: canto, dança, instrumentos e cursos de informática. Apesar de oferecer oficinas de ensino, a instituição tem como finalidade estimular o desenvolvimento cultural do indivíduo; seu público-alvo são crianças de 7 a 12 anos de famílias em estado de vulnerabilidade social, como o observado na resposta da coordenadora da Associação. Como o relatado abaixo:

Os objetivos são muito amplos, mas hoje a gente oferece oficinas, então ela abrange também essa parte através de projetos com alvo social através da cultura, educativo. [...] também oferecemos cursos de inglês. [...] o nosso alvo são crianças na faixa etária de 7 a 12 anos [...]Trabalhamos também a qualidade de vida" [...] com família em estado de vulnerabilidade, mas voltado para o social. (Entrevistado A1).

A Associação A iniciou suas atividades com voluntariado, mas, no decorrer do processo, observou a necessidade de remunerá-los, visto que os mesmos tinham gastos para cumprir com suas obrigações na instituição e teriam que despender tempo, como o apontado no trecho: "Hoje no seu quadro de funcionários conta somente com mão de obra remunerada, tendo em vista, o maior comprometimento das pessoas envolvidas nas ações" (Entrevistado A1). A prática de remuneração já havia sido levantada na literatura por Crisóstomo e Girão (2019) como diretiva para correção de deficiências nos sistemas de governança empresariais. Contudo, no caso de Associações, o IBGC (2016) recomenda a não remuneração direta ou indireta, devendo os membros assumirem seus cargos voluntariamente. Tanto em Crisóstomo e Girão (2019) quanto no IBGC (2016), o maior foco da contratação e remuneração está nos membros de Conselhos Administrativos, Fiscal e Diretoria Executiva. Em Celegatti et al. (2021), é encontrado de fato, no caso analisado, que os membros dos Conselhos não eram remunerados, condição já prevista no estatuto da entidade.

Tais achados anteriores na literatura permitem ressaltar e discutir a peculiaridade da Associação A, uma vez que esta, apesar de não remunerar os membros de seu Conselho de Administração, corroborando Celegatti et al. (2021), afirma ser necessária a remuneração de demais cargos e níveis organizacionais para o sucesso de suas atividades, assemelhando-se mais à proposição de Crisóstomo e Girão (2019). A justificativa da remuneração dos demais níveis organizacionais da Associação sustenta-se na percepção de que

O voluntário [pausa do entrevistado] o que acontece, ele funciona se for algo bem curto, se for uma coisa curta que tenha um prazo e seja um projeto curto, mas um projeto muito longo, por exemplo, para o ano todo ou uma turma de 6 meses, não funciona. Nós já tivemos voluntário sim, mas é dispendioso porque a pessoa começa a ter gasto. Por exemplo, para chegar até aqui ele precisa gastar com gasolina, precisa cumprir horário. Aí nós começamos a perceber que isso gera um custo para a pessoa. Hoje voluntário, aqui nós não temos nenhum todos são remunerados. No início era todos voluntários, depois nós fomos remunerando [...] (Entrevistado A1).

A associação faz parcerias com o governo e com empresas privadas por meio de projetos chancelados que, através de uma certificação concedida pelo Conselho Municipal dos Direitos da Criança e Adolescente, é dado o direito da instituição de captar recursos das empresas. Esses recursos são depositados no Fundo Municipal dos Direitos da Criança e Adolescente já com a indicação para qual instituição destinará o recurso.

Nós temos projetos chancelados pelo Conselho Municipal dos Direitos da Criança e Adolescente. É um projeto amplo e nós vamos trabalhar durante dois anos com esse projeto. Nós temos uma certidão do Conselho essa certidão ela nos dá o direito de arrecadar Fundos, nós apresentamos essa certidão em uma empresa e se essa empresa faz destinação para o fundo da Criança e Adolescente essa empresa pode destinar para nós através dessa certidão que certifica que nós estamos aptos para receber o recurso. (Entrevistado A1). 
Outra forma é através de Editais que são lançados pelo governo. Esses também são recursos do Fundo Municipal dos Direitos da Criança e Adolescente, porém sem destinação. Nessa modalidade, a Associação precisa apresentar os documentos legais de funcionamento bem como os projetos dentro da modalidade desejada, que serão analisados pelo Conselho e será dado o parecer.

Além de parcerias com o governo e empresas privadas através de editais e projetos a Associação, possui parceiras com pessoas físicas e pessoas jurídicas por meio de doações independentes e, ainda, realizam eventos próprios para arrecadação de recursos e, também, contam com a ajuda da igreja para suprir despesas não alcançadas por outras formas de captação de recursos.

A nossa realidade aqui é assim, além desses dois recursos nós temos parceiros que contribuem, pessoas físicas, jurídicas e também a igreja Batista Betel. Ela também faz toda a contrapartida dos projetos porque a prefeitura o estado não aplica em contrapartida. Então toda a contrapartida e o restante se faltarem, é a igreja que assume. (Entrevistado A1).

Como o observado, a associação A é uma instituição sem fins lucrativos, que presta serviços gratuitos para a comunidade através de oficinas culturais e de ensino, sua principal fonte de recursos são parcerias com o poder público e doações feitas por pessoas físicas e jurídicas. Tem como público-alvo crianças de faixa etária de 07 a 12 anos que estejam em situação de vulnerabilidade social.

Segundo o entrevistado A1, a igreja assume $40 \%$ de todas as despesas da Associação; os outros $60 \%$ são cobertos com recursos adquiridos de parcerias com o governo. Este ano, devido à Pandemia de Covid19, a Associação ficou impedida de realizar suas ações e, por consequência, não pode fazer uso de recursos públicos já adquiridos através dos processos existentes para parcerias com o mesmo. Os recursos utilizados para cobrir as despesas da associação, nesse período, foram os arrecadados através de doações com pessoas físicas e jurídicas.

A Associação B, fundada em 05 de outubro de 2005, é uma Associação que atende a todas as pessoas, desde crianças a idosos, independente de classe social, religião, raça ou nacionalidade, pois tem como finalidade dar ou devolver a dignidade humana para o indivíduo através de serviços gratuitos, tais como: a distribuição de cestas básicas, oferecimento de alimentos prontos, auxilio espiritual, cursos profissionalizantes e prestação de assistência com moradia. A associação tem como objetivo, também, formar cidadãos de bem, capazes de se manter economicamente e espiritualmente através do evangelho de Jesus, trabalhando a fraternidade, a parte moral e o sentimento de igualdade através da doutrina do amor.

O nosso foco é atender o ser humano. Nós trabalhamos com crianças, jovens, adultos e idosos de todas as classes sociais. A nossa finalidade é dar dignidade à pessoa. Por mais que nós assistimos a pessoa com cesta básica, isso é mais um atrativo para a pessoa vir até aqui. Antes de ele receber esses donativos ela passa por uma avaliação, cadastro para entendermos quais são suas necessidades. Então nós buscamos devolver para ela a dignidade e buscar estimular a força de vontade para que ela busque uma oportunidade, uma vida melhor. Nosso desafio é transformar essa pessoa em um ser humano de bem através de nossas atividades doutrinárias demonstrando a parte moral baseada no evangelho de Jesus (Entrevistado B1).

A instituição conta com aproximadamente 40 voluntários desde aqueles que estão completamente envolvidos, até aqueles que colaboram quando precisa. Entre os voluntários, estão os membros que compõem a Diretoria Executiva. A associação conta com mão de obra remunerada, distribuída entre os cargos de secretária, professora que dá aula para jovem aprendiz e jovem aprender - um projeto financiado com recursos públicos - e uma zeladora. Tem parceria com o poder público através de projetos nas modalidades FIA e Chancela no mesmo sistema da associação A. Associação, também, está desenvolvendo um projeto que tem por nome "Acolhida" e conta com a parceria da Pastoral Universitária, Exército Brasileiro e a OIM (Organização Internacional de Migração), que tem, como público-alvo, os refugiados da Venezuela, assistindo os mesmos com moradia, alimento, recolocando-os no mercado de trabalho. Esta assistência é prestada até o prazo máximo de 6 meses para a pessoa conseguir se estabelecer e continuar.

Nós pagamos o aluguel por 3 a 6 meses no máximo, até que eles possam se estabelecer e viver. Então ele já vai ter emprego fixo, ter dinheiro para dar condições de se manter. Nós os auxiliamos com aluguel, água, luz e comida até eles se estabelecerem e continuar [...] não é assistencialismo é oportunidade que nós proporcionamos de eles poderem viver, trabalhar e ter dignidade (Entrevistado B1).

Este cenário demonstra uma maior independência da Associação B dos recursos de origem pública, uma vez que suas parcerias mais relevantes se encontram na relação com as pessoas jurídicas e com outras entidades privadas, distinguindo-se da Associação A e assemelhando-se à Associação C. Dentre as 
distinções entre as Associações $A$ e $B$, encontra-se a atuação de voluntários. Como discutido durante a caracterização da Associação A, nesta, há uma necessidade e uma prerrogativa em contratar funcionários para o desenvolvimento de suas atividades, ponto relevante quando analisado o propósito do terceiro setor. Todavia, tal prerrogativa possivelmente se enquadra na Associação A em função de suas atividades culturais e de ensino que requerem certa profissionalização e um acompanhamento por mais tempo, diferente das atividades exercidas na Associação $B$, que têm uma forma de execução mais rápida e objetiva

Como apontado por Jorge, Souza e Vendruscolo (2021), algumas organizações sem fins lucrativas, apesar de menores, em função de suas atividades e projetos, requerem recursos e profissionais de elevada especialização, o que pode acarretar custos por sua própria natureza. Ainda que seja o caso, poder contar com voluntários ou necessitar de funcionários especializados, não invalida a contribuição das Associações, somente reforça as considerações que devem ser feitas durante o processo de gestão dessas entidades; caso contrário, o desempenho gerado pode tornar-se insatisfatório, custoso e menos atrativo para possíveis financiadores.

Por sua vez, a Associação C foi fundada no ano de 2000 para atender, exclusivamente, a homens migrantes, itinerantes, em trânsito, à população em situação de rua, a desabrigados, a imigrantes, a refugiados, sem distinção de classe, cor, raça, nacionalidade ou religião. Esse assistencialismo é dado de 3 (três) a 8 (oito) dias no semestre para homens que estão de passagem no município, oferecendo abrigo e as principais refeições do dia de forma gratuita.

art. $2^{\circ}$ - a casa de acolhida bom samaritano é uma entidade beneficente, sem fins lucrativos, e tem por finalidade prestar abrigo e fornecer refeição (as três principais: café, almoço e jantar) de forma gratuita, exclusivamente a homens migrantes, itinerantes, em trânsito, população em situação de rua, desabrigados, imigrantes, refugiados, sem distinção de classe, cor, raça, nacionalidade ou religião, de (3) três a 8(oito) dias por semestre, salvo os casos constantes e especificados no regimento interno, até o limite de 25 (vinte e cinco) vagas. (art. $2^{\circ}$ do estatuto, entrevistado $\mathrm{C} 1$ ).

É permitida a permanência do abrigado por mais dias em casos específicos previstos no estatuto da Associação, mas, normalmente, é permitida a permanência dos mesmos no abrigo somente de 3 a 8 dias a cada seis meses.

A instituição trabalha com mão de obra remunerada e voluntária, distribuída conforme o Código Civil/2002 e a lei específica das associações. Os voluntários estão distribuídos entre presidentes, vicepresidente, tesoureiro, secretária, conselho fiscal (três titulares e três suplentes) - composição da diretoria executiva. Por sua vez, a mão de obra remunerada conta com cinco e está distribuída entre os cargos de coordenação, cozinha, auxiliar de serviços gerais e vigilância. Esses são colaboradores contratados pelo regime celetista. Como o observado na fala da Presidente da associação.

Os voluntários estão distribuídos nos cargos previstos para as associaçães, o que vem previsto no código civil/2002 e na lei específica das associações. A [Associação C] tem presidente, vice-presidente, tesoureiro, secretária, conselho fiscal (três titulares e três suplentes). Há mão de obra remunerada (cinco colaboradores celetistas formais). A mão de obra remunerada é requisitada para coordenação, cozinha, auxiliar de serviços gerais e vigilância (Entrevistado C1).

A Associação C possui parceiras com a Prefeitura através da Secretaria Municipal de Assistência Social, por meio de Termo de Fomento. Os valores são recebidos mensalmente via convênio. Conforme a Presidente da Associação C expôs: "Sim, com a secretaria de desenvolvimento social (assistência social) do município de Lucas do Rio Verde" (Entrevistado C1).

Diante do exposto, a Associação C é uma Associação de assistencialismo que presta serviços gratuitos para homens que estão em estado de vulnerabilidade social, precisando de abrigo e de alimentação por um curto período de tempo.

\subsection{Análise conjunta dos casos em relação a Captação de Recursos e Práticas Gerenciais}

Nos casos analisados, foi identificado um padrão de fonte de financiamento de atividades embora todas as associações utilizem das fontes de recursos já preconizadas na literatura; cada uma apresenta uma fonte prioritária, conforme ilustrado na Figura 3. 
Figura 3 - Análise Conjunta baseada nas fontes de Financiamento

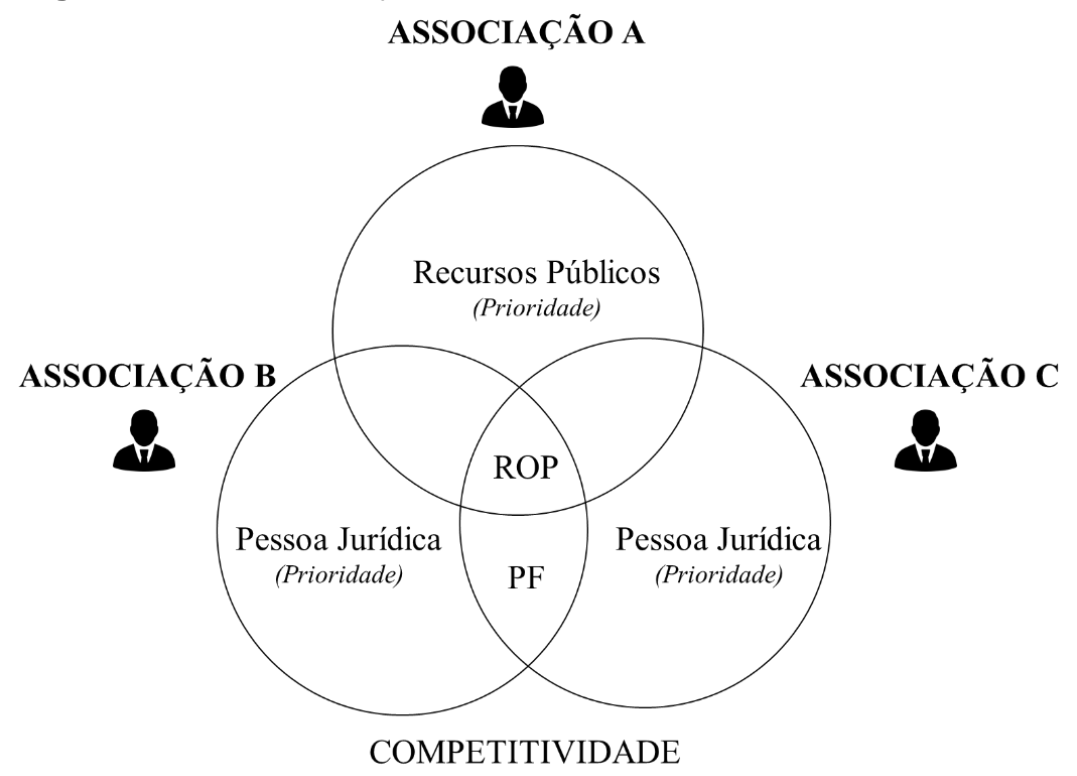

Fonte: Elaborado com base nos dados da pesquisa e modelo de Tozzi (2017).

Legenda: ROP - Recursos de origem própria; PF - Recursos de origem de pessoas físicas.

As três associações utilizam-se das quatro fontes de financiamentos apontadas em Tozzi (2017), portando editais para recursos públicos, parcerias para captação de recursos de pessoas jurídicas, doações diretas de pessoas físicas e os recursos gerados de forma própria. Contudo, a fonte de recurso prioritária, responsável por manter sua sustentabilidade e não comprometer sua existência, acaba direcionando algumas práticas nas associações.

A Associação A, como já comentado na subseção anterior, mantém suas atividades com recursos públicos governamentais, sendo esta sua principal fonte de recursos, e a igreja (pessoa jurídica), sua segunda maior subsidiária. A Associação B possui, como fonte principal, os recursos de origem das parcerias com pessoas jurídicas e doações de pessoas físicas. Já a Associação $C$ depende dos recursos públicos governamentais para custear sua folha de colaboradores e dos recursos de parcerias com pessoa jurídica (doações e ações direcionadas) para manutenção de suas atividades. A competitividade entre associações, por apresentarem eficiência, citada por Tozzi (2017), existe em certo grau, mas também é direcionada pela fonte prioritária de recursos, principalmente, se tratando de origem de parcerias com pessoas jurídicas.

$\mathrm{Na}$ visão do Entrevistado A1, a captação de recurso não deve ser individualista entre as associações, como o comentado: "eu acho que a minha instituição não é melhor que a outra, eu não sou prioridade. Só a minha Associação que precisa? Eu penso muito no coletivo". Para o Entrevistado A1, as parcerias com pessoa jurídica devem ser por eficiência e entrega e não por obrigação ou "apadrinhamento". Quando questionado sobre as estratégias da associação para captar recursos para se manter, complementou com:

"Eu não quero que ela [empresa] seja madrinha. Eu acredito que talvez, naquele momento pode existir uma outra Associação que precisa mais do que eu então eu não consigo fazer aquela coisa como se a empresa tivesse obrigação ou necessidade de contribuir para mim porque a minha Associação é mais importante do que as outras, todas são importantes. Eu consigo pensar assim... Olha eu atendo 200 crianças e eu apresento tais oficinas, tenho meu trabalho e se você gosta dele e quiser ajudar... Eu vou gastar muito, mas se ela não puder ajudar eu vou executar ele [trabalho] da mesma forma porque vão vir outras pessoas ajudar" (Entrevistado A1).

A competitividade, para o Entrevistado B1, também deve ser vista de uma forma coletiva, no caso de parcerias com pessoas jurídicas, uma vez que a forma de apresentação do trabalho ou as eficiências da associação são fatores essenciais para continuação e extensão do auxílio a outras associações. Como o relatado, quando questionado sobre as dificuldades da captação de recursos:

"A dificuldade sempre é o fator humano, somos nós mesmo. Muita gente não entende. Às vezes eu pedi e a pessoa pensa que é para mim. Tem muita gente que não pede ou tem vergonha de pedir. A pessoa gosta de trabalhar, mas ela não gosta de pedir. [...] Sempre tem, em todas as épocas, sempre houve, aquele que pede para si próprio, aquele que se aproveita de uma instituição, de um momento para usufruir para sim mesmo. Isso sempre interfere. 
Então, a gente tem instituições e pessoas que se usaram de entidades para se promover para pegar recursos... Isso é sempre um entrave, sempre um empecilho. Hoje eu já consigo lidar com isso com mais tranquilidade, mas primeiro eu ficava muito chateada e aborrecida, porque você não consegue provar para pessoa que você é diferente. Você só vai conseguir provar com o trabalho. Então a gente trabalha. A gente pede, se não quiser ajudar, não tem problema, a gente segue trabalhando. Então, acho que o fator humano sempre é o mais complicado".

Já para o Entrevistado C1, a principal dificuldade da captação de recursos "é a burocracia que envolve o processo". Os recursos de pessoas físicas não são tão comuns às associações analisadas, bem como já apontado por Morais et al. (2006). Quanto aos recursos de origem própria, observou-se, nas associações, que esses são para manter a sustentabilidade e não comprometer a existência na falta das demais fontes de recursos, também preconizado na literatura (MIRANDA; OLIVEIRA, 2019).

Dessa forma, assim como na literatura, as três associações analisadas contam, principalmente, com as origens de recursos públicos ou de pessoas jurídicas. Fato esse que realça a relevância do planejamento e o uso de ferramentas de prestação de contas, por imposição legal e/ou por produtividade e responsabilidade para com recursos de terceiros. Percebe-se, deste modo, que o fator humano e a burocracia são os direcionadores da captação de recursos nas três associações, consequentemente, orientam, também, os seus processos de prestação de contas.

Além das dificuldades operacionais apontadas pelas três associações analisadas, o fator competitividade por recurso foi fortemente levantado e, ainda que as associações se posicionem de uma forma menos agressiva em relação à disputa por financiadores, não quer dizer que seja um fator que deva ser ignorado nas práticas gerenciais para captação de recursos. Como apontado por Campos et al, (2020), o crescimento do terceiro setor no Brasil acirrou a disputa por recursos, acarretando o desenvolvimento de ações que em outros cenários eram de exclusividade do segundo setor em função da competitividade do mercado. Dessa forma, os achados, a partir das associações analisadas neste estudo, podem adotar estratégias do segundo setor, como marketing de relacionamento, abordado por Campos et al (2020), e estratégias para divulgação de informações, abordadas por Cunha e Matias-Pereira (2012), sem, necessariamente, assumir uma postura contraproducente em relação às demais associações.

O que é possível perceber nos discursos das associações é um temor pela competição, o que pode ser associado a uma certa falta de compreensão de práticas gerenciais inovadoras que fortaleçam o setor como um todo por meio da cooperação. Isto é, como apontado na literatura (TRUSSEL; PARSON, 2008; GODOY; RAUPP; TEZZA, 2016), os financiadores são motivados pela reputação, missão da entidade, estabilidade financeira e eficiência. Dessa forma, o domínio de estratégias que possibilitem a avaliação e o monitoramento, durante a prestação de contas, desses interesses favorece não a uma associação, mas a todo o setor.

Diante disso, a compilação das práticas gerenciais aplicadas ao processo de prestação de contas, nas três associações, foi analisada considerando as duas fontes principais de recursos, pública e de pessoa jurídica, a fim de identificar as possíveis semelhanças e divergências no uso das práticas gerenciais, conforme apresentado no Quadro 2.

Quadro 2 - Práticas Gerencias para Prestação de Contas a partir da Fonte de Recurso

\begin{tabular}{|c|c|}
\hline Dimensão & Descrição \\
\hline \multicolumn{2}{|r|}{ Associação A } \\
\hline Controle dos recursos captados & $\begin{array}{l}\text { - Sistema de Prestação de Contas Governamental "Novo Convênio" } \\
\text { (Recursos públicos). } \\
\text { - Contabilidade (recursos próprios e doações de pessoa jurídica e } \\
\text { pessoa física). }\end{array}$ \\
\hline $\begin{array}{l}\text { Gestão centralizada ou } \\
\text { descentralizada dos projetos }\end{array}$ & - Elaboração centralizada na coordenação. \\
\hline $\begin{array}{l}\text { Suporte especializado para tomada } \\
\text { de decisão }\end{array}$ & $\begin{array}{l}\text { - Controle Interno Municipal. } \\
\text { - Acessória da contabilidade. }\end{array}$ \\
\hline Sistema de controle de gastos & $\begin{array}{l}\text { - Plano de aplicação (quando se trata de recursos públicos). } \\
\text { - Controles físicos impressos (notas fiscais, cheques, recibos) } \\
\text { quando se trata das outras fontes de recursos (próprios, doações } \\
\text { e pessoas jurídicas). }\end{array}$ \\
\hline Práticas gerenciais utilizadas & $\begin{array}{l}\text { - Análise de Relatórios Contábeis. } \\
\text { - Registro de contas a pagar e a receber e movimentação bancária. }\end{array}$ \\
\hline $\begin{array}{l}\text { Monitoramento da efetividade das } \\
\text { atividades }\end{array}$ & $\begin{array}{l}\text { - Relatório mensal das atividades. } \\
\text { - Registro de Frequências. }\end{array}$ \\
\hline
\end{tabular}




\begin{tabular}{|c|c|}
\hline & - Registro Fotográfico. \\
\hline $\begin{array}{l}\text { Monitoramento da efetividade dos } \\
\text { resultados }\end{array}$ & $\begin{array}{l}\text { - Assembleia Geral. } \\
\text { - Eventos para os pais com apresentação das crianças atendidas } \\
\text { pelo projeto. } \\
\text { - Envio eletrônico de fotos e relatórios de gastos para as pessoas } \\
\text { jurídicas. }\end{array}$ \\
\hline \multicolumn{2}{|r|}{ Associação B } \\
\hline Controle dos recursos captados & $\begin{array}{l}\text { - Sistema de Prestação de Contas Governamental "Novo Convênio" } \\
\text { (Recursos públicos). } \\
\text { - Contabilidade (recursos próprios e doações de pessoa jurídica e } \\
\text { pessoa física). }\end{array}$ \\
\hline $\begin{array}{l}\text { Gestão centralizada ou } \\
\text { descentralizada dos projetos }\end{array}$ & - Elaboração centralizada na Diretoria (vice-presidente). \\
\hline $\begin{array}{l}\text { Suporte especializado para tomada } \\
\text { de decisão }\end{array}$ & $\begin{array}{l}\text { - Controle Interno Municipal. } \\
\text { - Acessória da contabilidade. }\end{array}$ \\
\hline Sistema de controle de gastos & $\begin{array}{l}\text { - Análise de Relatórios Contábeis. } \\
\text { - Registro de contas a pagar e a receber e movimentação bancária. }\end{array}$ \\
\hline Práticas gerenciais utilizadas & $\begin{array}{l}\text { - Análise de Relatórios Contábeis. } \\
\text { - Registro de contas a pagar e a receber e movimentação bancária, } \\
\text { controle de caixa. } \\
\text { - Controle de custos e despesas. } \\
\text { - Controle de estoque. }\end{array}$ \\
\hline $\begin{array}{l}\text { Monitoramento da efetividade das } \\
\text { atividades }\end{array}$ & $\begin{array}{l}\text { - Através de contratação de jovens aprendiz. } \\
\text { - Pessoas que são recuperadas do álcool e das drogas. } \\
\text { - Feedback das pessoas atendidas pela Associação. } \\
\text { - Caixa de sugestões. }\end{array}$ \\
\hline $\begin{array}{l}\text { Monitoramento da efetividade dos } \\
\text { resultados }\end{array}$ & $\begin{array}{l}\text { - Assembleia Geral. } \\
\text { - Reuniões Administrativas. } \\
\text { - Envio eletrônico de fotos e relatórios de gastos para as pessoas } \\
\text { jurídicas. }\end{array}$ \\
\hline \multicolumn{2}{|r|}{ Associação C } \\
\hline Controle dos recursos captados & $\begin{array}{l}\text { - Sistema de Prestação de Contas Governamental "Novo Convênio" } \\
\text { (Recursos públicos). } \\
\text { - Contabilidade (recursos próprios e doações de pessoa jurídica e } \\
\text { pessoa física). }\end{array}$ \\
\hline $\begin{array}{l}\text { Gestão centralizada ou } \\
\text { descentralizada dos projetos }\end{array}$ & $\begin{array}{l}\text { - Elaboração descentralizada participação dos colaboradores } \\
\text { limitada a função de sua responsabilidade. (vice-presidente). }\end{array}$ \\
\hline $\begin{array}{l}\text { Suporte especializado para tomada } \\
\text { de decisão }\end{array}$ & $\begin{array}{l}\text { - Contador. } \\
\text { - Diretoria Executiva da Associação. } \\
\text { - Controle Interno Municipal e } \\
\text { - Gerente do Banco. }\end{array}$ \\
\hline Sistema de controle de gastos & $\begin{array}{l}\text { - Controle físico. } \\
\text { - Sistemas de contabilidade. } \\
\text { - Planilhas de Excel e } \\
\text { - Pacotes multiusuários. }\end{array}$ \\
\hline Práticas gerenciais utilizadas & $\begin{array}{l}\text { - Contabilidade. } \\
\text { - Controle de caixa. } \\
\text { - Controle de contas a pagar. } \\
\text { - Controle de contas a receber. } \\
\text { - Retrole de estoques. } \\
\text { - Orçamo sobre investimento. } \\
\text { - Planejamento tributário. } \\
\text { - Ponto de equilíbrio e } \\
\text { - Planejamento estratégico. }\end{array}$ \\
\hline $\begin{array}{l}\text { Monitoramento da efetividade das } \\
\text { atividades }\end{array}$ & $\begin{array}{l}\text { - Diretoria da Executiva. } \\
\text { - Desempenho do colaborador em relação à execução das suas }\end{array}$ \\
\hline
\end{tabular}




\begin{tabular}{|l|l|}
\hline & atividades cotidiana. \\
\hline $\begin{array}{l}\text { Monitoramento da efetividade dos } \\
\text { resultados }\end{array}$ & $\begin{array}{l}\text { - Diretoria da Executiva. } \\
\text { - Controle de documentos; controle de atividades e projetos. } \\
\text { - Autoavaliação para correção de práticas. }\end{array}$ \\
\hline
\end{tabular}

Fonte: Elaborado com dados da pesquisa (2020).

As três Associações analisadas fazem o controle dos recursos captados através da contabilidade e do sistema Novo Convênio próprio da Prefeitura para a prestação de contas. Atualmente, as três associações possuem recursos Públicos. As associações A e B possuem recursos captados através de editais; a Associação $C$ possui recurso público captado através de convênios. Por isso, fazem uso do sistema.

No que tange à gestão dos projetos, nas associações $A$ e $B$, a gestão é feita de forma centralizada uma vez que a elaboração se concentra somente na coordenação e na vice-presidente da associação, respectivamente. Na Associação A, quem elabora os projetos é a coordenadora; após o plano pronto, é apresentado apenas para o presidente da associação para o conhecimento do mesmo; enquanto, na Associação $\mathrm{B}$, os projetos são elaborados pela vice-presidente e apresentados à diretoria, caso haja sugestões, é analisada para decidir se enquadra no projeto. A Associação $C$ tem uma dinâmica descentralizada dos projetos. Na elaboração, busca-se a opinião e a ideias de todos os colaboradores de acordo com função de cada um. A diretoria da associação $C$ tem participação direta na criação dos mesmos.

$\mathrm{Na}$ dimensão de suporte especializado, as associações A e B contam com a contabilidade e Controle Interno Municipal para as tomadas de decisões uma vez que a contabilidade das associações analisadas é feita pelo escritório de contabilidade. Eles também têm o suporte técnico do Controle interno Municipal para prestação de contas e outras dúvidas que possuírem quanto à aplicação dos recursos públicos. $\mathrm{Na}$ associação C, o suporte é dado pelo contador, diretoria executiva da associação, controle interno municipal e gerente do banco. A Associação $C$ tem a Diretoria Executiva dinâmica e participativa, pois a mesma conta com a composição da sua diretoria executiva, com profissionais da área do direito, contabilidade e administração. Por essa razão, tem uma maior autonomia na hora de tomar decisões, mas, ainda assim, conta com apoio do Gerente de Banco e com o controle Interno Municipal nas mesmas situações das Associações A e B. Percebe-se, na Associação C, que a implementação das práticas de contabilidade gerencial e a frequência de uso são mais evidentes e estruturadas por meio da contribuição de diversas áreas, um dos motivos pode ser a diversidade na composição da sua diretoria executiva que, como preconiza Gasparetto (2021), em seus achados, é um dos aspectos que influenciam para a implementação das práticas gerenciais que não apenas resultam em informações para uso da gestão superior, mas para uso nas estratégias de captação de recursos.

Para controlar os gastos, a Associação A utiliza o plano de aplicação que trata de uma palhinha em que está todo o planejamento de como vai ser gasto o recurso adquirido com o governo. Assim, faz-se uso do plano de aplicação para acompanhar onde os recursos públicos já foram aplicados e o que ainda falta executar. Utilizam-se, também, controles físicos, como: notas fiscais, cheques, recibos, entre outros, para controlar os gastos dos recursos captados de fontes próprias, doações e pessoas jurídicas.

No resultado da associação $B$, identificou-se a análise de Relatórios Contábeis, registro de contas a pagar e a receber e movimentação bancária. Existe uma pessoa que é denominada como tesoureiro, que fica responsável pelo contas a pagar e receber e pela movimentação bancária. Fazem a análise dos demonstrativos contábeis para identificar e controlar seus gastos uma vez que, na composição da Diretoria executiva, existem membros que são contadores.

$\mathrm{Na}$ Associação C, o controle é feito de forma semelhante à das outras associações através de Controle físico, sistemas de contabilidade, planilhas de Excel, pacote multiusuários. A associação $C$ também conta com um Conselho Fiscal que, na pessoa do tesoureiro, registra todos os gastos da associação a serem apresentados à Diretoria em reuniões periódicas para o conhecimento de todos.

As práticas gerenciais utilizadas na Associação A são identificas quando a mesma faz a análise dos relatórios contábeis, uma vez que a associação é uma empresa sem fins lucrativos e tem as mesmas obrigatoriedades de uma empresa privada. As práticas gerenciais também se mostram através do Registro de contas a pagar e a receber e da movimentação bancária.

A Associação B também usa como práticas gerenciais, na associação, a Análise de Relatórios Contábeis; registro de contas a pagar e a receber e movimentação bancária, controle de caixa, controle de custos e despesas e controle de estoque, assemelhando-se com às associações A e $\underline{\mathrm{C}}$. Na Associação C, identificou-se, também, a análise de relatórios contábeis, controle de caixa, controle de contas a pagar, controle de contas a receber, controle de estoques, retorno sobre investimento, orçamento, planejamento tributário, ponto de equilíbrio e planejamento estratégico. Mostrando-se ser uma associação com mais recursos e mais experiências administrativas, que conta com mais mão de obra técnica e qualificada para a gestão da mesma.

Para monitoramento da efetividade das atividades realizadas, a associação A utiliza relatório das 
atividades que são relatórios dos conteúdos repassados para as crianças através das oficinas, registro de frequências. Dessa forma, monitorando a participação do aluno nas ações executadas, bem como fazendo registros fotográficos para reforçar o monitoramento dos frequentadores das atividades oferecidas pela associação.

$\mathrm{Na}$ associação B, esse monitoramento é feito através da contratação de jovens aprendizes, que é um trabalho realizado pela instituição em parcerias com as empresas privadas para treinar jovens que estão tento, pela primeira vez, um emprego. É levado em consideração, para o monitoramento, a quantidade de pessoas resgatadas do álcool e das drogas, o Feedback das pessoas atendidas pela Associação através do trabalho da doutrina espírita e através de caixa de sugestões, estendida para todas as pessoas que estão envolvidas direta ou indiretamente na associação.

A associação $C$ faz o monitoramento de forma presencial através dos membros da diretoria em que é observado o desempenho de todos os colaboradores de acordo com as funções e, também, a forma do atendimento prestado aos usuários e a quantidade de pessoas que estão sendo atendidas mensalmente.

O automonitoramento e avaliação são primordiais e consistentes com uma boa gestão, visto que, como apontado na literatura (VASCONCELOS et al., 2021), há a necessidade de constante monitoramento de regras e códigos implementados nas execuções das atividades a fim de detectar possíveis falhas e fornecer condições ao gestor de refletir sobre as práticas da entidade.

Quanto à efetividade dos resultados, as Associações A e B realizam as assembleias gerais, porém se distinguem em outros aspectos. A associação $A$ realiza eventos com os pais, com apresentações culturais das crianças atendidas pelo projeto para mostrar o desempenho e os resultados alcançados com as crianças, para as empresas privadas. Feito o envio eletrônico de fotos e relatórios de gastos, bem como informações dos eventos realizados com as crianças, assim como a associação B que faz o envio eletrônico de fotos e relatórios de gastos, ainda faz reuniões administrativas para apresentar os resultados periódicos para os membros da Diretoria. A associação $\mathrm{C}$ a fim de monitorar a efetividade dos resultados à diretoria faz um rigoroso controle de documentos, controle de atividades e projetos desenvolvidos no âmbito da entidade, autoavaliando-se e corrigindo práticas quando necessário.

Após a análise e a percepção fornecida pelas Associações, é possível perceber diversas ferramentas e práticas preconizadas pela literatura (CELEGATTI et al., 2021; VASCONCELOS et al., 2021; GASPARETTO, 2021) como relevante no processo de gestão de organizações da sociedade civil e na captação de recursos. Entretanto, considerando os pressupostos de Trussel e Parson (2008) em relação a profissionalização da gestão beneficia a captação de recursos a partir de informações divulgadas pelas próprias OSCs quanto à eficiência na alocação de recursos, a estabilidade financeira, a reputação e a missão da entidade e situação de seus beneficiários as Associações fazem uso dessas informações muito internamente. O que representa uma falta, pois seus resultados e desempenho deveriam ser mais trabalhados e evidenciados profissionalmente no momento da captação de recursos, portanto na negociação, visto que informações direcionarão a decisão dos financiadores por injetar recursos e fomentar a continuidade dessas entidades.

\section{CONSIDERAÇÕES FINAIS}

O objetivo deste estudo foi identificar e analisar as formas de captação de recursos e as práticas gerenciais para prestação de contas em Organizações da Sociedade Civil (OSC), sendo aplicado um estudo de casos múltiplos com três associações atuantes no Município de Lucas do Rio Verde - MT. A partir da análise dos casos individuais e conjuntos, foi possível alcançar o objetivo proposto e apontar algumas considerações quanto a possível relação entre a fonte principal de recurso mantenedora das associações e a adoção de determinadas práticas gerenciais para a sua prestação de contas.

Os achados indicam que, quando a fonte de recursos provém de recursos públicos, a prestação de contas é realizada em sistema interno do órgão de repasse. Dessa forma, o registro da prestação de contas pode contar com a contabilidade para melhor controle das contas. Quando a origem dos recursos provém de recursos privados de pessoa jurídica, o uso da contabilidade e das práticas gerenciais, na prestação de contas, é mais frequente, a fim de demonstrar os resultados de seus investimentos.

As contribuições desta análise está na melhor compreensão do papel da captação de recursos sobre as decisões de uso das práticas gerenciais por associações, uma vez que essas entidades possuem papel social chave na sociedade, fornecendo suporte à própria administração pública que não suporta toda a demanda da população. A prestação de contas é primordial nestas associações, pois suas atividades, em geral, são mantidas por recursos obtidos de terceiros que, no exercício da doação, possuem direito de requisitar a prestação de contas.

A responsabilidade dessa prestação é do gestor da associação, portanto, se não adequada ao poder público ou à outra fonte de recurso, pode acarretar perda desse subsídio. As associações, analisadas neste estudo, já possuem certo grau de formalização na prestação de contas, utilizando práticas, tais como: análise de relatórios contábeis, controle de contas a pagar, controle de disponibilidades bancárias, orçamento, análise 
de ponto de equilíbrio, entre outras. Todavia, houve um processo de aprendizado até os estágios que se encontram.

Isto posto, sugere-se, como pesquisas futuras, em uma abordagem qualitativa, o estudo de associações iniciantes e seu acompanhamento em conjunto com órgão regulador, a fim de analisar as dificuldades iniciais dos gestores dessas organizações no momento do nascimento da associação. Em uma vertente mais quantitativa, sugere-se a análise de um número maior de associações atuantes em outras regiões do país para relacionar fonte de captação de recurso, práticas gerenciais utilizadas na prestação de contas e aspectos psicológicos e/ou cognitivos da diretoria, unificando uma visão econômica, social e psicológica das associações do país.

Neste estudo, considerando suas limitações metodológicas, foi possível associar apenas a dimensão econômica e alguns traços da social, enquanto posicionamento utilizado para captar recursos. Contudo, houve indícios de possíveis associações mais profundas entre a direção, a escolha do recurso e a forma de prestação de contas que podem ser mais bem abordadas em um estudo mais abrangente.

\section{REFERÊNCIAS}

ANANIAS, jacqueline et al. Prestação de Contas e Captação de Recursos: estudo em entidades do terceiro setor do estado do paraná. In: Anais do Congresso USP de Iniciação Científica em Contabilidade, São Paulo, SP, Brasil. 2020.

ANDRADE, Álvaro Pereira de et al. Manual de procedimentos para o terceiro setor: aspectos de gestão e de contabilidade para entidades de interesse social. Conselho Federal de Contabilidade (CFC): Brasília. Profis, 2015.

ARAÚJO, Anderson Andrade et al. O Marco Regulatório das Organizações da Sociedade Civil: terceiro setor e as rganizações de pequeno e grande portes. Revista lbero-Americana de Humanidades, Ciências e Educação, v. 7, n. 7, p. 884-896, 2021.

BORGES, Nusia Maria Ferreira; COSTA, Ângelo Fernandes; CLAUDIO, R. A. Z. A. O Terceiro Setor: um estudo empírico em gestão, controle e captação de recursos. Facit Business and Technology Journal, v. 1, n. 5, 2018.

CAMPOS, LUCILA et al. Elementos do marketing na captação de recursos do terceiro setor. RAM. Revista de Administração Mackenzie, v. 8, p. 104-127, 2020.

CELEGATTI, Nathan et al. Práticas de Governança Corporativa: o caso de uma entidade do terceiro setor. ConTexto, v. 21, n. 49, p. 73-85, 2021.

CRISÓSTOMO, vicente lima; GIRÃO, aline maria coelho. Análise do compliance das empresas brasileiras às boas práticas de governança corporativa. Revista Ambiente Contábil. Universidade Federal do Rio Grande do Norte-ISSN 2176-9036, 11.2: 40-64, 2019.

CUNHA, José Humberto Cruz; MATIAS-PEREIRA, José. Captação de recursos no terceiro setor: fatores estratégicos para divulgação de informações. Revista Contemporânea de Contabilidade, v. 9, n. 18, p. 83-102, 2012.

GIL, Antonio Carlos et al. Como elaborar projetos de pesquisa. São Paulo: Atlas, 2002.

GIL, Antonio Carlos. Métodos e técnicas de pesquisa social. 6. ed. Ediitora Atlas SA, 2008.

IBGC. Guia das Melhores Práticas para Organizações do Terceiro Setor: Associações e Fundações.

2016. Disponível em: < https://www.ibgc.org.br/noticias/19784/IBGC-lanca-Guia-das-MelhoresPraticas-paraOrganizacoes-do-Terceiro-Setor>. Acesso em: 06 nov. 2021

INNOCENTI, Renícia; GASPARETTO, Valdirene. Práticas de Contabilidade Gerencial no Terceiro Setor: O Desafio da Gestão Eficiente. Administração Pública e Gestão Social, 2021.

JORGE, Fernanda Santos; SOUZA, Ângela Rozane Leal de; VENDRUSCOLO, Maria Ivanice. Custos no Terceiro Setor: Um Panorama Quantitativo e Qualitativo da Produção Científica Nacional. Pensar Contábil, v. 23, n. 80, 2021.

LORCA, Mariana Cristina Betti Cury; AVRICHIR, Ilan. Orientação Empreendedora na Captação de Recursos Internacionais das Organizações da Sociedade Civil. BBR, Braz. Bus. Rev., Vitória, v. 17, n. 2, 2020.

MAPA DAS ORGANIZAÇÕES DA SOCIEDADE CIVIL @. Dados e Indicadores. Instituto de Pesquisa Econômica Aplicada. Disponível em: <https://mapaosc.ipea.gov.br/dados-indicadores.html>. Acesso em: 16.05.2020.

MEDEIROS, Arícia Aryane Silva. 0 desafio da captação de recursos no terceiro setor: o caso da instituição Casa do Pobre. 2017. Trabalho de Conclusão de Curso. Universidade Federal do Rio Grande do Norte.

MELO, Albenici Correia de et al. Conformidade no processo de captação de recursos pelas organizações do terceiro setor. 2018. Dissertação. Universidade Presbiteriana Mackenzie.

MELO, Albenici Correia; DE SOUZA VASCONCELOS, Ana Lucia Fontes. Práticas de integridade no processo de captação de recursos pelas organizações do terceiro setor. Práticas Em Contabilidade e Gestão, v. 5, n. 2, 2017.

MENDONÇA, Patrícia Maria Emerenciano de; SEGATTO, Catarina lanni. Reflexões sobre a relação entre as Organizações da Sociedade Civil (OSCs) e o Estado: Marco legal, mecanismos de financiamento e implicações para a gestão. Anais, 2014 
MIRANDA, Raissa A. Mira Campos; DE OLIVEIRA, Neide Aparecida Arruda. Captação e Gestão de Recursos no terceiro Setor: sustentabilidade e transparência das Entidades do terceiro Setor. Revista H-TEC Humanidades e Tecnologia, v. 3, n. 1, p. 154-175, 2019.

MILANI FILHO, M. A. F.; MILANI, A. M. M. Governança no terceiro setor: estudo sobre uma organização francesa do século XIX. Revista Eletrônica de Ciência Administrativa, v. 10, n. 1, p. 32-46, 2011.

MORAIS, A. C. B. et al. Manual do Terceiro Setor. Jardim Paulista: INSTITUTO PRO BONO, 2006.

MORGAN, Levi; BENEDICTO, Gideon Carvalho. Um estudo sobre a controladoria em organizações do terceiro setor na Região Metropolitana de Campinas. Revista de Administração da UNIMEP, v. 7, n. 3, p. 111-133, 2009.

NAKAGAWA, Masayuki; RELVAS, Tania Regina Sordi; DIAS, José Maria, Filho. Accountability: a razão de ser da contabilidade. Revista de Educação e Pesquisa em Contabilidade, v. 1, n. 3, p. 83-100, 2007.

NATRIELLI NETO, Antonio; GUIMARO JUNIOR, Orlando. Manual das Associações: Como constituir e administrar uma associação. Secretaria Municipal de Desenvolvimento Social, 2011.

OLIVEIRA JUNIOR, José Lupércio Ramos de. O Terceiro Setor no Brasil do contexto histórico ao marco regulatório da lei 13.019/14. 2018.

OLIVEIRA, Alan Santos; CALLADO, Antônio André Cunha. O perfil dos representantes de Organizações Não Governamentais (ONGs) brasileiras é relacionado com a utilização de práticas gerenciais de mensuração de desempenho?/Is the profile of representatives of Brazilian Non-Governmental Organizations (NGOs) related to the use of performance measurement management practices?. Brazilian Journal of Development, v. 4, n. 6, p. 2855-2875, 2018.

OLIVEIRA, Alríca Mara Donald. Terceiro setor. 2018. Trabalho de Conclusão de Curso. Faculdades IDAAM.

OLIVEIRA, Guilherme César de. Gestão organizacional nas Atléticas: um estudo sobre gerenciamento das

Associações Atléticas Acadêmicas do DF. 2016. 69 f., il. Monografia (Bacharelado em Administração) Universidade de Brasília, Brasília, 2016.

PARENTE, Tobias Coutinho et al. Gestão de mudanças nas organizações do terceiro setor: o desafio da sustentabilidade financeira. Gestão \& Regionalidade, v. 28, n. 84, 2012.

PLANALTO. Disponível em: <http://www.planalto.gov.br/ccivil_03/LEIS/L9790.htm>. Acesso em: 05 de mai. de 2020.

RIFKIN, Jeremy. Identidade e natureza do terceiro setor. IOSCHPE, Evelyn. $3^{\circ}$ Setor: desenvolvimento social sustentável. Rio de Janeiro: Paz e Terra, 1997.

ROCHA, Marie Cristine Fortes; GONÇALVES, Hermínia F. Marketing Social Como Estratégia de Negócio Para Captação de Recursos no Terceiro Setor. International Journal of Business Marketing, v. 2, n. 2, p. 3-20, 2017.

SANTOS, Andreia Ap Pandolfi; DA SILVA, Moacir Gomes. Gestão de Finanças no Terceiro Setor. Revista Visão: Gestão Organizacional, v. 4, n. 1, p. 22-35, 2015.

SANTOS, Rubens da Costa. Reflexões sobre as Organizações da Sociedade Civil: documento de trabalho. São Paulo. Disponível em< http://www. integracao. fgvsp. br/9e10/artigorubens. doc>. Acessado em, v. 13, 2010.

SANTOS, Yone da Costa; NEGRÃO, Keila Regina Mota; SABOYA, Sabrina Machado Petrola. Estratégias para Captação de Recursos no Terceiro Setor: um estudo multicaso aplicado na apae belém e apae barcarena. Revista de Administração e Contabilidade-RAC, v. 5, n. 10, p. 175-213, 2018.

SILVA, Carlos Eduardo Guerra. Gestão, legislação e fontes de recursos no terceiro setor brasileiro: uma perspectiva histórica. Rev. Adm. Pública. vol.44 nº.6 Rio de Janeiro Nov./Dec. 2010.

SILVA, Elton Praxedes Carvalho; DE VASCONCELOS, Sandra Stöckli; NORMANHA ARANTES FILHO, Miguel. Organizações do Terceiro Setor: Desafios na captação de recursos para sua gestão. Qualis Sumaré-Revista Acadêmica Eletrônica, v. 6, n. 2, 2016.

SILVA, M. N.; COSTA, A. C. V.; GÓMEZ, C. R. P. Sustentabilidade no terceiro setor: o desafio de harmonizar as dimensões da sustentabilidade em uma ONG. REUNA, Belo Horizonte, v. 16, n. 3, p. 75-92, 2011.

SOARES, Lara Perla Quadros et al. Captação de Recursos no Terceiro Setor. Encontro Internacional de Gestão, Desenvolvimento e Inovação (EIGEDIN), v. 5, n. 1, 2021.

TOZZI, José Alberto. ONG sustentável: o guia para organizações do terceiro setor economicamente prósperas. Editora Gente Liv e Edit Ltd, 2017.

TRUSSEL, John M.; PARSONS, Linda M.. Financial Reporting Factors Affecting Donations to Charitable Organizations. Advances in Accounting, v. 23, p. 263-285, 2008.

VASCONCELOS, Ana Lúcia Fontes de S. et al. Práticas de Conformidade no Processo de Captação de Recursos das Organizações do Terceiro Setor. Práticas em Contabilidade e Gestão, v. 9, n. 1, p. 1, 2021. 
